\title{
Metal carbonyl anions as model metal-centered nucleophiles in aromatic and vinylic substitution reactions
}

\author{
Petr K. Sazonov, Vasyli A. Ivushkin, Galina A. Artamkina, and Irina P. Beletskaya* \\ Moscow State University, Chemistry Department, \\ Moscow, 119992, Leninskie Gory 1, GSP-2, Russian Federation \\ E-mail: beletska@org.chem.msu.ru
}

Dedicated to Professor Roberto A. Rossi

(received 21 Jul 03; accepted 27 Sep 03; published on the web 02 Oct 03)

\begin{abstract}
The mechanism of reactions of metal carbonyl anions, [CpFe(CO) $]_{2}^{-},\left[\operatorname{Re}(\mathrm{CO})_{5}\right]^{-}$and $\left[\mathrm{Mn}(\mathrm{CO})_{5}\right]$, with various polyfluorinated $(\mathrm{Hal}=\mathrm{Cl}, \mathrm{Br}, \mathrm{I})$ and non-fluorinated $(\mathrm{Hal}=\mathrm{Br}, \mathrm{I})$ aryl and alkenyl halides has been examined with the help of anion trapping experiments. Reactions discussed in this communication are shown to proceed via the initial attack of metal carbonyl anion on halogen. The halogen-metal exchange mechanism is demonstrated by the trapping of the intermediate aryl (alkenyl) carbanion and by the formation of halo(acyl)metallate anions cis$\left[\mathrm{R}(\mathrm{CO}) \mathrm{M}(\mathrm{CO})_{4} \mathrm{Hal}\right]^{-}$instead of $\mathrm{RM}(\mathrm{CO})_{5}$ complexes $(\mathrm{M}=\mathrm{Re}, \mathrm{Mn})$ in the reactions with $\left[\operatorname{Re}(\mathrm{CO})_{5}\right]^{-}$and $\left[\mathrm{Mn}(\mathrm{CO})_{5}\right]^{-}$. The yield of nucleophilic substitution products varies widely from trace in certain reactions with $\left[\mathrm{CpFe}(\mathrm{CO})_{2}\right]^{-}$, which give the $\left[\mathrm{CpFe}(\mathrm{CO})_{2}\right]_{2}$ dimer, to quantitative in reactions with $\left[\mathrm{Re}(\mathrm{CO})_{5}\right]^{-}$.
\end{abstract}

Keywords: Reaction mechanisms, $\mathrm{S}_{\mathrm{N}} \mathrm{Ar}, \mathrm{SNV}$, halogen-metal exchange, carbonylmetallates

\section{Introduction}

The traditional idea of a nucleophilic agent in organic chemistry implies an electron-rich molecule incorporating an electronegative element $(\mathrm{O}, \mathrm{N}, \mathrm{S}, \mathrm{Hal})$ as the nucleophilic centre. Such were the models in the classical studies of the $\mathrm{S}_{\mathrm{N}} 2$ and $\mathrm{S}_{\mathrm{N}} 1$ substitution mechanisms at the $\mathrm{sp}^{3}$ carbon and of addition-elimination $\left(\mathrm{Ad}_{N} \mathrm{E}\right)$ mechanism at the $\mathrm{sp}^{2}$ carbon. However, the progress of organometallic chemistry in the second half of the $\mathrm{XX}$ century gave rise to nucleophilic agents of another type, where the reactive centre is located on an electropositive element - main group or transition metal. In many aspects of chemical reactivity (supernucleophilicity, "supersoftness" and high reducing power) these metal-centred anions are essentially different from conventional "electronegative” nucleophiles. 
Not all metal-centred anions are supernucleophiles, in fact some of them (e.g. $\left[\mathrm{V}(\mathrm{CO})_{6}\right]^{-1}$ ) are scarcely more nucleophilic than water, but others (such as $\left[\mathrm{R}_{3} \mathrm{Sn}\right]^{-2}$, or $\left[\mathrm{CpFe}(\mathrm{CO})_{2}\right]^{-3,4}$ ) are very reactive and the Co-centred $\mathrm{B}_{12 \mathrm{~s}}{ }^{-}$and related cobaloxime anions, ${ }^{5}$ and $\mathrm{Ni}(\mathrm{I})$ porphyrin anion ${ }^{6}$ were claimed to be the most powerful nucleophiles on record. Their ability to react with unactivated aryl and vinyl halides, which are inert towards conventional nucleophiles, forms another aspect of their exceptional nucleophilic reactivity. ${ }^{6-14}$

The term "supersoftness" is used to refer to much higher affinity of metal-centred anions towards organic substrates with soft leaving groups, e.g. higher than usual $\mathrm{k}_{\mathrm{I}} / \mathrm{k}_{\mathrm{OTos}}$ or $\mathrm{k}_{\mathrm{I}} / \mathrm{k}_{\mathrm{Br}}$ ratios. While evident already in aliphatic $\mathrm{S}_{\mathrm{N}} 2$ reactions, ${ }^{4-6,15}$ in aromatic and vinylic substitution with metal centred anions the leaving group effect is often reversed: from $\mathrm{F}>>\mathrm{Cl}, \mathrm{Br}$, I typical for $\mathrm{Ad}_{\mathrm{N}} \mathrm{E}$ mechanism it changes to $\mathrm{I}>\mathrm{Br}>\mathrm{Cl}>\mathrm{F} .-8,12,14-18$

The last but not least is the high reducing power of metal-centred nucleophiles. Their reactions with organic halides formally considered as nucleophilic are frequently accompanied by the formation of dehalogenated or homocoupled products.

The above mentioned peculiarities of metal-centred nucleophiles call for mechanistic interpretation, which in the past three decades was dominated by single electron transfer (SET) paradigm. A number of fine experimental techniques (ESR, CIDNP, radical traps and "radical clocks", stereochemical probes) and sophisticated theoretical concepts ${ }^{19}$ were applied to prove the reaction mechanism (Scheme 1), in which SET from the anion to the electrophile precedes the bond formation. The resulting radical pair intermediates, may either collapse giving the nucleophilic substitution product or dissociate giving the reduction or homocoupling products. Sufficiently detailed studies were carried out so far only for the aliphatic nucleophilic substitution (NS), and in certain cases positive evidence of SET pathway was obtained. ${ }^{10,15,19,20}$

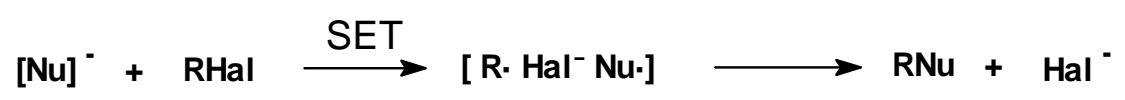

\section{Scheme 1}

The mechanisms of substitution with metal-centred anions at the $\mathrm{sp}^{2}$-carbon centre, in aromatic and vinylic series, are far less explored. However, more and more evidence emerges that these reactions follow heterolytic mechanisms, involving some transition metal - halogen interactions in the transition state. ${ }^{14,16,17}$ An extreme case of these, and the only one clearly defined and easily verified, is the halogen-metal exchange (HME) pathway (Scheme 2).

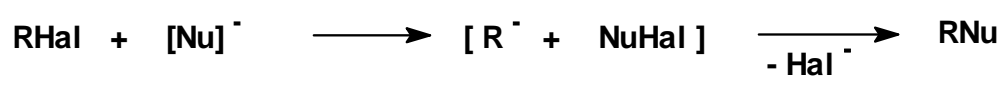

\section{Scheme 2}


The HME mechanism of the reaction of $\left[\mathrm{R}_{3} \mathrm{Sn}\right]^{-}$nucleophiles with unactivated aryl halides, originally discovered by H.G. Kuivila, ${ }^{12}$ has been confirmed in a recent study by R.A. Rossi. ${ }^{16}$ Our own studies have revealed that metal carbonyl anions are another large group of nucleophiles which can react via HME pathway with polyfluorinated aryl $l^{21,22}$ and alkenyl ${ }^{23}$ halides. Here we will give a brief account of these studies including new data on the reactions of metal carbonyl anions (carbonylates) with non-fluorinated aryl and vinyl halides.

\section{Results and Discussion}

Efficient stabilization of the incipient carbanion by fluorine substituents makes the polyfluorinated aryl and vinyl halides particularly good substrates for halophilic reactions. Dehalogenation of bromo- and iodopentafluorobenzenes with soft enolate ${ }^{24}$ or sulphur ${ }^{25}$ nucleophiles is believed to proceed via halophilic mechanism.

Metal carbonylates react via HME pathway with all the three halopentafluorobenzenes (Hal $=\mathrm{Cl}, \mathrm{Br}, \mathrm{I})^{22}$. The same is true of bromo and certain chloropolyfluoroalkenes: bromotrifluoroethylene (2), 1,2-difluoro-2-t- $\mathrm{Bu}_{F}$-1-bromo and 1-chloro ethylenes (3-Br and 3-

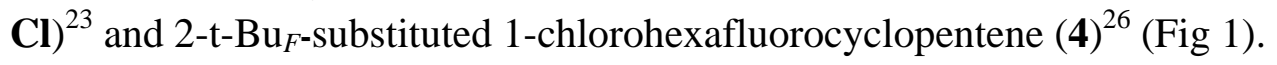

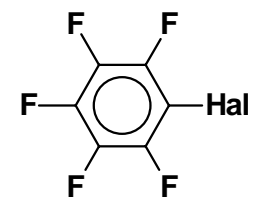

$\mathrm{Hal}=\mathrm{Cl}(1-\mathrm{Cl}), \mathrm{Br}(1-\mathrm{Br}), \mathrm{I}(1-\mathrm{I})$

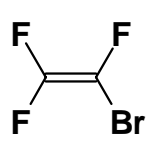

2

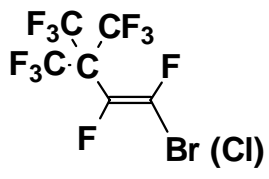

3-Br (Cl)

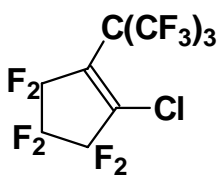

4

Figure 1. Polyfluorinated substrates reacting with carbonylates via HME pathway.

Yet, in several other polyfluoroalkenyl chlorides, namely Z- and $E$-chlorodifluorostyrenes ${ }^{26,27}$ and 1-chloro-2-(trifluoromethyl)hexafluorocyclopentene ${ }^{26}$ (Fig. 2), NS with carbonylates follows "normal" $\operatorname{Ad}_{N} E$ pathway (Scheme 3). HME in that case is only a side process leading to the dehalogenation of the alkenyl halide.
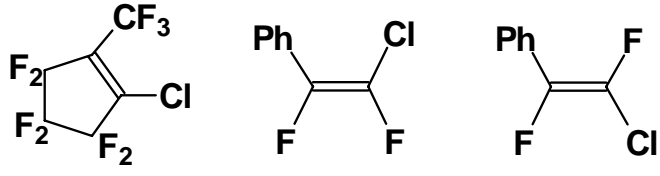

Figure 2. Vinyl halides, reacting with carbonylates by $\operatorname{Ad}_{N} E$ mechanism. 


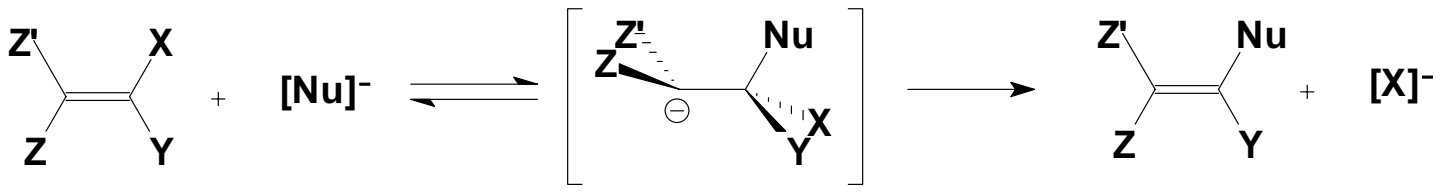

Scheme 3. Addition-elimination mechanism $\left(\mathrm{Ad}_{\mathrm{N}} \mathrm{E}\right)$ of nucleophilic vinylic substitution.

The halophilic reactions of metal carbonyl anions with aryl and vinyl halides 1 - 4 (Fig. 1) do not always lead to NS products, and these do not necessarily have the structure of $\sigma$-aryl(vinyl) complexes of metal carbonyls.

The most reactive carbonylate $\left[\mathrm{CpFe}(\mathrm{CO})_{2}\right] \mathrm{K}$ produces in these reactions the corresponding $\sigma$-aryl(vinyl) complexes together with $\left[\mathrm{CpFe}(\mathrm{CO})_{2}\right]_{2}$ dimer in varying proportions, which depends on the organic halide (Table 1). The yield of NS products is moderately high (up to $77 \%$ ) with pentafluorohalobenzenes, quite modest with bromoalkenes (22-30\%) and drops down negligible with chloroalkenes.

Table 1. Reactions of polyfluorinated aryl and alkenyl halides $\left(\mathrm{R}_{F} \mathrm{Hal}\right)$ with $\left[\mathrm{CpFe}(\mathrm{CO})_{2}\right] \mathrm{K}$, $\mathrm{THF}^{22,23,26}$

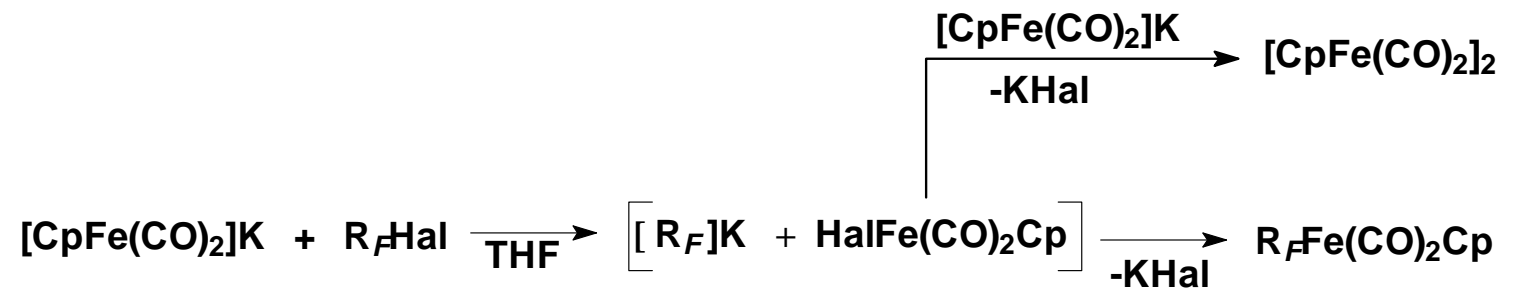

\begin{tabular}{lcccl}
\hline $\begin{array}{l}\text { Aryl (alkenyl) } \\
\text { Halide }\end{array}$ & \multicolumn{3}{c}{ Product yields, \% } \\
\hline $\mathrm{R}_{F} \mathrm{Hal}$ & $\mathrm{t},{ }^{\circ} \mathrm{C}$ & $\mathrm{R}_{F} \mathrm{Fe}(\mathrm{CO})_{2} \mathrm{Cp}$ & {$\left[\mathrm{Fe}(\mathrm{CO})_{2} \mathrm{Cp}\right]_{2}$} & Other products \\
\hline $1-\mathrm{Cl}$ & 20 & 58 & 39 & $\mathrm{C}_{6} \mathrm{~F}_{5}\left(\mathrm{C}_{6} \mathrm{~F}_{4}\right)_{\mathrm{n}} \mathrm{C}_{6} \mathrm{~F}_{4} \mathrm{Cl}, 7 \%(\mathrm{n}=0-3)$ \\
$1-\mathrm{Br}$ & 20 & 54 & 40 & $\mathrm{C}_{6} \mathrm{~F}_{5}\left(\mathrm{C}_{6} \mathrm{~F}_{4}\right)_{\mathrm{n}} \mathrm{C}_{6} \mathrm{~F}_{4} \mathrm{Br}, 7 \%(\mathrm{n}=0-3)$ \\
$1-\mathrm{I}$ & 20 & 77 & 23 & $\mathrm{C}_{6} \mathrm{~F}_{5} \mathrm{H}, 10 \%$ \\
2 & -50 & 30 & 60 & \\
$3-\mathrm{Br}$ & -50 & 22 & 60 & \\
$3-\mathrm{Cl}$ & -50 & 3 & 90 & \\
4 & -50 & $<1$ & 90 & \\
\hline
\end{tabular}

Much more selective are the reactions with $\left[\mathrm{Re}(\mathrm{CO})_{5}\right] \mathrm{Na}$, giving the NS products in high and often quantitative yields (80-95\%). However, these products are not the $\sigma$-aryl(vinyl) complexes $\mathrm{R}_{F} \mathrm{Re}(\mathrm{CO})_{5}$, but are the halo(acyl)rhenate anions (Scheme 4). Similarly built halo(acyl)manganate anions $\left[\mathrm{C}_{6} \mathrm{~F}_{5}(\mathrm{CO}) \mathrm{Mn}(\mathrm{CO})_{4} \mathrm{Hal}\right]^{-}$formed in the reactions of 1-Br and 1-I 
with $\left[\mathrm{Mn}(\mathrm{CO})_{5}\right] \mathrm{K}$ are unstable and readily decompose (in a matter of hours) to "normal" $\sigma$-aryl complex $\mathrm{C}_{6} \mathrm{~F}_{5} \mathrm{Mn}(\mathrm{CO})_{5}{ }^{22}$

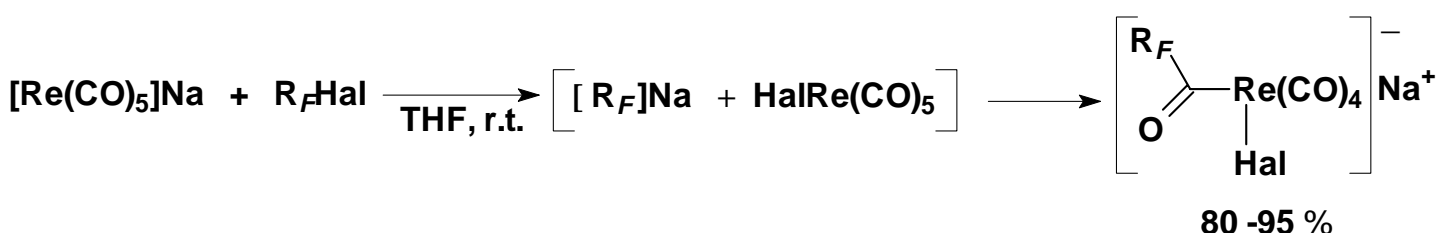

Scheme 4. Reaction of polyfluorinated aryl and alkenyl halides $\left(\mathrm{R}_{F} \mathrm{Hal}\right)$ with $\left[\mathrm{Re}(\mathrm{CO})_{5}\right] \mathrm{Na}$.

Notwithstanding the apparent non-uniformity, the initial process in all these reactions is the halophilic attack by the carbonylate (vide infra).

To demonstrate the HME mechanism we have always relied upon two mechanistic probes: (a) anion trapping experiments (b) formation of halo(acyl)rhenate anions in the reaction with $\mathrm{Re}(\mathrm{CO})_{5} \mathrm{Na}$.

The aryl (alkenyl) carbanion intermediate can be "trapped” by proton donors (Scheme 5). When the reactions are carried out in the presence of $t-\mathrm{BuOH}$ or $\mathrm{CH}$-acid ${ }^{28}$ the formation of NS products, both $\sigma-\mathrm{R}_{F}$-complexes and halo(acyl)metallate anions, is suppressed completely and instead $\mathrm{R}_{F} \mathrm{H}$ products are formed (usually 35-50\%). The carbonylate is usually converted to the corresponding dimer (though, $\mathrm{Re}(\mathrm{CO})_{5} \mathrm{Hal}$ are also formed). ${ }^{22,23}$

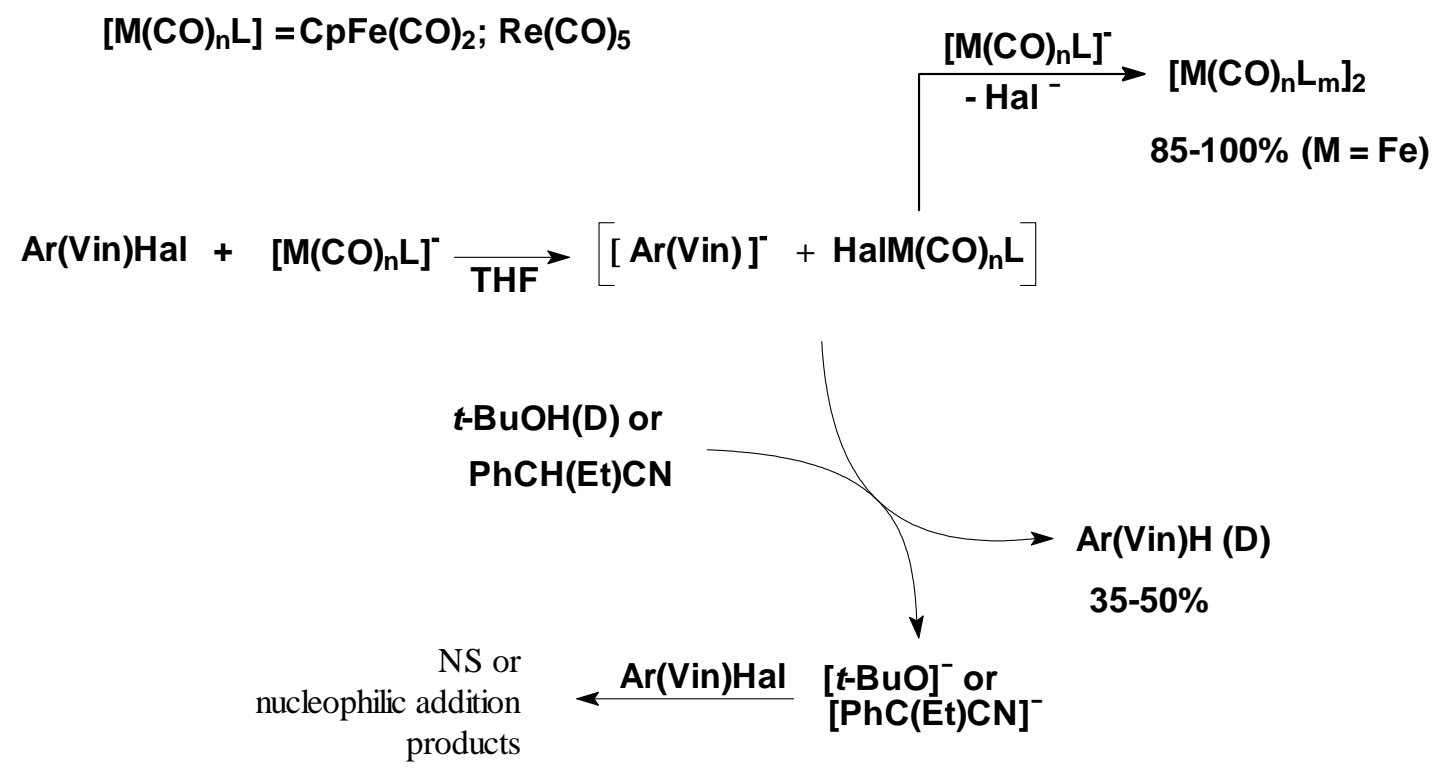

Scheme 5. Trapping of intermediate carbanion by proton donors.

Formation of halo(acyl)rhenate anions gives us an even simpler, but no less reliable test for the HME mechanism, which, we may say, is imprinted in their structure. Halo(acyl)rhenates contain structurally intact fragments of aryl (alkenyl) carbanion and $\operatorname{Re}(\mathrm{CO})_{5} \mathrm{Hal}$, and their 
formation by a carbanion addition reaction, having good literature precedence, ${ }^{29}$ may be considered as an "autotrapping" of the HME intermediates. ${ }^{23}$

As it is already evident only the heavy halogen $(\mathrm{Cl}, \mathrm{Br}, \mathrm{I})$, but not fluorine is substituted by carbonylates. This is noteworthy, since common "electronegative" nucleophiles, ${ }^{30}$ and even "soft" carbanions ${ }^{22,23}$, substitute fluorine in such substrates as $\mathbf{1 - B r}, \mathbf{1 - C l}$ or $\mathbf{2}$, as is only to be expected for $\mathrm{Ad}_{\mathrm{N}} \mathrm{E}$ mechanism (shown on Scheme 3 for an alkenyl halide).

Bromides showed higher reactivity than the corresponding chlorides, however only lower limits of the intermolecular element effect $\mathrm{k}_{\mathrm{Br}} / \mathrm{k}_{\mathrm{Cl}}$ could be evaluated ( $>100$ for the 1-I/1-Cl pair with $\left[\mathrm{Mn}(\mathrm{CO})_{5}\right] \mathrm{K},{ }^{22}$ and $>20$ for $\mathbf{3}-\mathbf{B r} / \mathbf{3}-\mathbf{C l}$ pair with $\left.\left[\mathrm{Re}(\mathrm{CO})_{5}\right] \mathrm{Na}^{23}\right)$. All the reactions with bromides take place instantaneously upon the reactant mixing.

Halophilic reactions with polyfluoroalkenyl halides 3-Br and 3-Cl proceed with retention of their original $Z$ configuration in all the reaction products: $\sigma$-alkenyl metal complexes, halo(acyl)rhenates and protodehalogenated alkenes $\mathrm{R}_{F} \mathrm{H}^{23}$

On the whole the observed chemistry is not consistent with SET mechanism and free radical intermediates (Scheme 1), nor with the classical $\mathrm{Ad}_{\mathrm{N}} \mathrm{E}$ mechanism (Scheme 3), but agrees well with HME mechanism and aryl (alkenyl) carbanion intermediates. Arguments against SET for the reactions with alkenyl halides have been already discussed in full detail elsewhere. ${ }^{23}$

High halogen electrophilicity makes HME-pathway particularly easy for polyfluorinated substrates, but what about common, non-fluorinated aryl and vinyl halides? How do they react with metal carbonyl anions?

We have examined the reactions of carbonylates with several representative aryl and vinyl halides: weakly activated $p$-iodobenzonitrile (5), an $\alpha$-activated methyl $Z$ - $\alpha$-bromocinnamate (6), a rather active heterocyclic bromide 2-bromo-1,3-thiazole (7) and unactivated $\beta$-iodostyrene (8) (Table 2). Following our usual procedure of HME tests, the reactions with $\left[\mathrm{CpFe}(\mathrm{CO})_{2}\right] \mathrm{K}$ were performed with and without anion trap $(t-\mathrm{BuOD})$, and reactions with $\left[\mathrm{Re}(\mathrm{CO})_{5}\right] \mathrm{Na}$ were checked for halo(acyl)metallate formation. The tests proved positive in all cases examined. Halo(acyl)rhenate anion 9 was the sole product of the reaction of $\left[\mathrm{Re}(\mathrm{CO})_{5}\right] \mathrm{Na}$ with $\mathbf{5}$ (Scheme 6). Similarly, two isomeric ( $\mathrm{Z}$ and $\mathrm{E}$ ) halo(acyl)rhenate anions were formed (90\% total yield, 7:2 isomer ratio) in its reaction with 6.

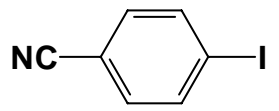

5

(1)
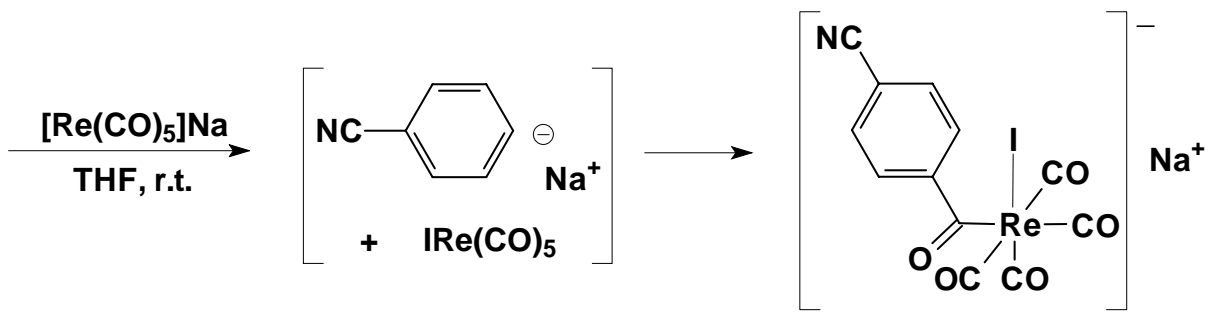

9

Scheme 6. Reaction of $p$-iodobenzonitrile with $\left[\mathrm{Re}(\mathrm{CO})_{5}\right] \mathrm{Na}, \mathrm{THF}, 20^{\circ} \mathrm{C}$. 
Unfortunately, the reactions with $\left[\mathrm{CpFe}(\mathrm{CO})_{2}\right] \mathrm{K}$ gave only minor or even trace amounts of the NS products, the reaction with bromide 7 being the only exception (64\% yield). In other cases $\left[\mathrm{CpFe}(\mathrm{CO})_{2}\right]_{2}$ dimer was the main reaction product. However, in the presence of $t$-BuOD even these traces of NS products were removed, and, what is more important, near to stoichiometric amounts (35-50\%) of mono deuterated arens and alkenes RD were produced (Table 2). The stoichiometric yield of RD (RH) in a HME process would be $50 \%$ exactly, since only half of $\left[\mathrm{CpFe}(\mathrm{CO})_{2}\right] \mathrm{K}$ reacts with the organic halide, the second half being consumed in a very fast ${ }^{31}$ reaction with $\mathrm{CpFe}(\mathrm{CO})_{2} \mathrm{Hal}$ (Scheme 5).

Table 2. Reactions of $\left[\mathrm{CpFe}(\mathrm{CO})_{2}\right] \mathrm{K}$ with non-fluorinated aryl and vinyl halides in THF. The effect of $t$-BuOD $(t-\mathrm{BuOH})^{\mathrm{a})}$

\begin{tabular}{|c|c|c|c|c|c|c|c|}
\hline \multicolumn{4}{|c|}{ Aryl (alkenyl) halide } & \multicolumn{4}{|c|}{ Product yields, $\%^{\mathbf{b})}$} \\
\hline \multicolumn{2}{|c|}{ RHal } & $\mathrm{t},{ }^{\circ} \mathrm{C}$ & $\begin{array}{l}\text { Anion } \\
\text { trap }\end{array}$ & $\mathrm{RFe}(\mathrm{CO})_{2} \mathrm{Cp}$ & $\mathrm{RD}$ & RH & {$\left[\mathrm{Fe}(\mathrm{CO})_{2} \mathrm{Cp}\right]_{2}$} \\
\hline & & 30 & none & 8 & $-^{c)}$ & 46 & 92 \\
\hline & 5 & 20 & $t$-BuOD & $<1$ & 50 & $<1$ & 100 \\
\hline & 6 & -50 & none & $4^{\text {d) }}$ & - & $<4$ & 85 \\
\hline $\mathrm{C}_{6} \mathrm{H}_{5}^{\prime}$ & & & $t$-BuOD & $<1$ & 35 & 4 & 95 \\
\hline & 7 & 20 & none & 64 & - & $<2$ & 36 \\
\hline & 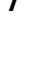 & 20 & $t-\mathrm{BuOH}$ & $<2$ & - & 45 & 100 \\
\hline & 9 & 2 & none & 3 & - & 41 & 70 \\
\hline & $\mathbf{0}$ & 20 & $t$-BuOD & $<0.5$ & 35 & 6 & 86 \\
\hline
\end{tabular}

a) Reactions were carried out with a slight excess of RHal (5-20\%) and 5-10 equivalents of $t$ BuOD.

b) As determined by ${ }^{1} \mathrm{H}$ NMR spectroscopy.

c) No source of deuterium.

d) With the lithium salt of $\left[\mathrm{CpFe}(\mathrm{CO})_{2}\right]^{-}$the yield of $\mathrm{RFe}(\mathrm{CO})_{2} \mathrm{Cp}$ increases to $15 \%$.

In case of $\beta$-iodostyrene and $p$-iodobenzonitrile up to $45 \%$ of styrene or benzonitrile, respectively, is formed even without an anion trap (Table 2). The corresponding styryl and $p$ cyanophenyl carbanions ( $\mathrm{pKa} \approx 32-37$ of the parent $\mathrm{CH}$-acids ${ }^{32}$ ) are much stronger bases than polyfluorinated carbanions. Presumably, they can abstract a proton from some other source besides $t$-BuOD, such as the organic halide or the Cp-group of some iron carbonyl product. 


\section{Conclusions}

Metal carbonyl anions belong to those few nucleophiles, that can give NS products via HME process, which appears to be a rather general reactivity pattern for their reactions with aryl and alkenyl halides. It is by no means limited to polyfluorinated compounds, which is shown on several non-flurinated bromides and iodides. While definite conclusions would be premature, we suppose that HME is the only possible pathway for a spontaneous reaction of weakly activated or non-activated aromatic and vinylic bromides (all the more so for iodides) with metal carbonyl anions.

However, many of the halophilic reactions discussed in this paper are ineffective from a synthetic viewpoint. The major problem lies in the two-stage NS via HME mechanism itself (Scheme 2). The ease of the first HME step does not necessarily guarantee that NS product will be formed on the second step because of various competing reaction pathways of HME intermediates. The main one apparently is the reaction of $\mathrm{CpFe}(\mathrm{CO})_{2} \mathrm{Hal}$ with $\left[\mathrm{CpFe}(\mathrm{CO})_{2}\right] \mathrm{K}$ producing the ubiquitous $\left[\mathrm{CpFe}(\mathrm{CO})_{2}\right]_{2}$ dimer. ${ }^{31}$ Thus, high reactivity of the metal carbonyl halide towards carbanions and high selectivity of this reaction, as is the case with $\operatorname{Re}(\mathrm{CO})_{5} \mathrm{Hal}$, are also important for obtaining the NS products in high yields.

\section{Experimental Section}

General Procedures. Preparation of metal carbonyl anion salts and their reactions with organic halides were carried out in "all-fused" glassware using vacuum-line techniques. Less airsensitive materials, such as the reaction products, were handled under argon atmosphere, when necessary. THF was vacuum-transferred from sodium benzophenone ketyl. Experiments with polyfluorinated aryl and vinyl halides have been described previously. ${ }^{21-23,26}$

$\left[\mathrm{CpFe}(\mathrm{CO})_{2}\right] \mathrm{K}$ was obtained quantitatively (95-98\%) by reductive cleavage of the dimer $\left[\mathrm{CpFe}(\mathrm{CO})_{2}\right]_{2}$ with excess of $\mathrm{NaK}_{2.8}$ alloy $\left(0.10-0.15 \mathrm{ml}\right.$ per $1 \mathrm{mmol}$ of dimer). ${ }^{33}\left[\mathrm{Re}(\mathrm{CO})_{5}\right] \mathrm{Na}$ was prepared by the reduction of $\mathrm{Re}_{2}(\mathrm{CO})_{10}$ with $0.5 \% \mathrm{NaHg}$ (30-50\% excess) and purified by the low temperature crystallisation from THF. ${ }^{34} t$-BuOD was obtained by the action of $\mathrm{D}_{2} \mathrm{O}$ on

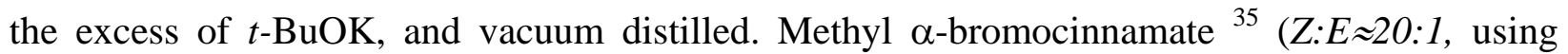
procedure with piperidine) and iodostyrene ${ }^{36}(Z: E \approx 1: 4)$ were prepared according to published procedures.

Break-seal ampoules were used for the transfer of substances. Volatile compounds were dried over the appropriate drying agent and deoxygenated by several freeze-pump-thaw cycles. Small portions required for a single experiment were placed (volatiles - vacuum transferred) into thin-walled glass spheres, which were sealed off under vacuum.

The ${ }^{1} \mathrm{H}$ NMR $(400 \mathrm{MHz})$ and ${ }^{13} \mathrm{C}(100,56 \mathrm{MHz})$ spectra were recorded on a Varian VXR-400 spectrometer at room temperature. Solvent signals were used for the chemical shift reference. IR spectra of reaction mixtures and isolated products were recorded using UR-20 spectrophotometer 
in THF in $0.2 \mathrm{~mm} \mathrm{CaF}_{2}$ cell. Mass spectra were recorded on a MS-890 spectrometer, with electron impact ionisation, $70 \mathrm{eV}$ ionising energy, the direct inlet method, with a source temperature of $150^{\circ} \mathrm{C}$.

NMR spectroscopy was used as a primary tool for the analysis of reaction solutions. The yields of the products discussed above are purely spectroscopic, based upon the relative integral intensity of the signals of the products and the signal of internal standard (durene or $\left(\mathrm{Me}_{3} \mathrm{Si}\right)_{2} \mathrm{O}$ ) in ${ }^{1} \mathrm{H}$ NMR spectra of reaction solutions. ${ }^{21}$ The signals were referenced to the individual products by comparison to the spectra of the isolated compounds or with the literature data for the compounds previously described, including two iron carbonyl derivatives: $\mathrm{PhCH}=\mathrm{CHFe}(\mathrm{CO})_{2} \mathrm{Cp}^{37}$ and $p-\mathrm{CNC}_{6} \mathrm{H}_{4} \mathrm{Fe}(\mathrm{CO})_{2} \mathrm{Cp} .{ }^{38}$

Reactions of $\left[\operatorname{Re}(\mathrm{CO})_{5}\right] \mathrm{Na}$ with $p$-iodobenzonitrile (5) and methyl $\alpha$-bromocinnamate (6). Typically $0.2-0.5 \mathrm{ml}$ of $\left[\mathrm{Re}(\mathrm{CO})_{5}\right] \mathrm{Na}$ solution in THF $\left(c \sim 0.3 \mathrm{~mol} \cdot \mathrm{l}^{-1}\right)$ was mixed at r.t. with 5$20 \%$ excess of organic halide, internal standard (durene or $\left(\mathrm{Me}_{3} \mathrm{Si}\right)_{2} \mathrm{O}$ ), and the resulting solution was immediately decanted into NMR sample. The halo(acyl)rhenate complexes formed were characterized in solution by ${ }^{1} \mathrm{H}$ and ${ }^{13} \mathrm{C}$ NMR and IR spectroscopy. Cis-[p$\left.\mathbf{C N C}_{6} \mathbf{H}_{4}(\mathbf{C O}) \operatorname{Re}(\mathbf{C O})_{4} \mathrm{I}\right] \mathrm{Na}:{ }^{1} \mathrm{H}$ NMR $(\delta$, THF): 7.37 (d, $J=8 \mathrm{~Hz}, 2 \mathrm{H}), 7.59$ (d, $\left.J=8 \mathrm{~Hz}, 2 \mathrm{H}\right)$. IR

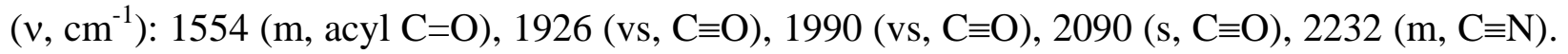
Cis- $\left[\mathbf{C}_{6} \mathbf{H}_{5} \mathbf{C H}=\mathbf{C}\left(\mathbf{C O}_{2} \mathrm{Me}\right)(\mathbf{C O}) \mathbf{R e}(\mathbf{C O})_{4} \mathbf{B r}\right] \mathbf{N a}$ (main isomer): ${ }^{1} \mathrm{H}$ NMR $(\delta, \mathrm{THF}): 7.54(\mathrm{~s}, 1 \mathrm{H}$, $\mathrm{CH}=$ ), 7.39 (m, 2H, $\mathrm{C}_{6} H_{5 \text { ortho }}$ ), 7.28 (m, $\mathrm{C}_{6} \mathrm{H}_{5 \text { meta }}$ ), 7.22 (m, $\left.1 \mathrm{H}, \mathrm{C}_{6} H_{5 \text { para }}\right){ }^{13} \mathrm{C} \mathrm{NMR}(\delta$, THF): 263.16 (acyl $\mathrm{C}=\mathrm{O}), 190.98(2 \times \mathrm{C} \equiv \mathrm{O}), 189.73(\mathrm{C} \equiv \mathrm{O}), 189.68(\mathrm{C} \equiv \mathrm{O}), 170.42\left(\mathrm{CO}_{2} \mathrm{Me}\right), 142.64$ $(\mathrm{CH}=)$, 129.82, 129.50, $129.30\left(\mathrm{C}_{6} \mathrm{H}_{5}\right), 51.74\left(\mathrm{CH}_{3}\right)$, the remaining signals of two quaternary carbons could not be identified on the background of weak signals belonging to the other isomer. IR (mixture of isomers, v, $\mathrm{cm}^{-1}$ ): 1550 (m br, acyl C=O), 1725 (m, CO${ }_{2} \mathrm{Me}$ ), 1742 (s, $\mathrm{CO}_{2} \mathrm{Me}$ )

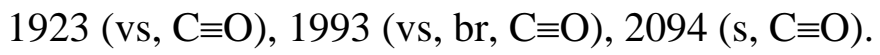

Reaction of [CpFe(CO) $\left.)_{2}\right] \mathrm{K}$ with 2-bromo-1,3-thiazole (7). [CpFe(CO) $\left.)_{2}\right] \mathrm{K}$ prepared from 36.7 $\mathrm{mg}\left[\mathrm{CpFe}(\mathrm{CO})_{2}\right]_{2}(0.207 \mathrm{mmol})$ and $\mathrm{NaK}_{2.8}(0.03 \mathrm{ml})$ in $2 \mathrm{ml}$ THF was mixed with $34.6 \mathrm{mg} 7$ $(0.211 \mathrm{mmol})$. The reaction mixture was separated by column chromatography on silica gel (Fluca, 40/63) with 3:1 petroleum ether:chloroform as eluent. First red fraction containing $\left[\mathrm{CpFe}(\mathrm{CO})_{2}\right]_{2}$ was discarded. The following yellow fraction was collected to give after solvent removal $14 \mathrm{mg}$ of the NS product $\mathbb{N}_{N}^{S}-\mathrm{Fe}(\mathrm{CO})_{2} \mathrm{Cp}(0.054 \mathrm{mmol}) .{ }^{1} \mathrm{H} \mathrm{NMR}(\delta, \mathrm{THF}): 7.62(\mathrm{~d}$, 1H, J=3.3 Hz), 7.17 (d, 1H, J=3.3 Hz), 5.11 (s, Cp). IR (v, cm ${ }^{-1}$ ): 1995 (vs, C $\left.\equiv 0\right), 2040$ (vs, $\mathrm{C} \equiv \mathrm{O})$.

Reactions of $\left[\mathrm{CpFe}(\mathrm{CO})_{2}\right] \mathbf{M}\left(\mathbf{M}=\mathbf{K}\right.$, Li) with methyl $\boldsymbol{\alpha}$-bromocinnamate (6). $\left[\mathrm{CpFe}(\mathrm{CO})_{2}\right] \mathrm{Li}$ was prepared from $70 \mathrm{mg}\left[\mathrm{CpFe}(\mathrm{CO})_{2}\right]_{2}(0.39 \mathrm{mmol})$ and $\sim 0.3 \mathrm{ml}$ of $0.3 \% \mathrm{LiHg}$ in $\sim 4 \mathrm{ml} \mathrm{THF}^{39}$ The obtained orange-brown solution was cooled to $-50^{\circ} \mathrm{C}$ and $95 \mathrm{mg}$ of compound 6 (0.39 mmol) was introduced, the color immediately changing to dark cherry. Reaction mixture was separated by column chromatography on silica gel (Fluca, 40/63) with 4-6:1 petroleum ether: $\mathrm{Et}_{2} \mathrm{O}$ as eluent. First fraction, containing some starting 6 was discarded, the next fraction 
(64 mg after solvent removal) contained mainly $\left[\mathrm{CpFe}(\mathrm{CO})_{2}\right]_{2}$, after which the yellow band of the NS product was eluted to give after solvent removal $20 \mathrm{mg}(0.059 \mathrm{mmol}$, 15\%) of $\mathbf{C}_{6} \mathbf{H}_{5} \mathbf{C H}=\mathbf{C}\left(\mathbf{C O}_{2} \mathbf{M e}\right) \mathbf{F e}(\mathbf{C O}){ }_{2} \mathbf{C p} .{ }^{1} \mathrm{H}$ NMR $\left(\delta\right.$, acetone- $\left.d_{6}\right): 7.21$ (t, 2H, $\left.\mathrm{C}_{6} H_{5 m e t a}\right), 7.13$ (d, 2H, $\left.\mathrm{C}_{6} H_{5 o r t h o}\right), 7.08$ (d, 1H, $\mathrm{C}_{6} H_{5 \text { para }}$ ), 7.13 (d, 2H, $\mathrm{C}_{6} \mathrm{H}_{5 \text { ortho }}$ ), 6.432 (s, 1H, CH=), 5.126 (s, 5H. Cp), 3.624 (s, 3H, $\left.\mathrm{CH}_{3}\right)$. MS (m/z): $310[\mathrm{M}-\mathrm{CO}]^{+}(2 \%), 282[\mathrm{M}-2 \mathrm{CO}]^{+}(20 \%), 223[\mathrm{M}-2 \mathrm{CO},-$ $\left.\mathrm{CO}_{2} \mathrm{Me}\right]^{+} \quad(10 \%), \quad 186 \quad\left[\mathrm{FeCp}_{2}\right]^{+} \quad(40 \%), \quad 162 \quad\left[\mathrm{C}_{6} \mathrm{H}_{5} \mathrm{CH}=\mathrm{CHCO}_{2} \mathrm{Me}\right]^{+} \quad(50 \%), 131$ $\left[\mathrm{C}_{6} \mathrm{H}_{5} \mathrm{CH}=\mathrm{CHCO}\right]^{+}(100 \%), 103\left[\mathrm{C}_{8} \mathrm{H}_{7}\right]^{+}(70 \%), 102\left[\mathrm{C}_{8} \mathrm{H}_{6}\right]^{+}(70 \%), 77\left[\mathrm{C}_{6} \mathrm{H}_{5}\right]^{+}(40 \%) . \mathrm{IR}(v$,

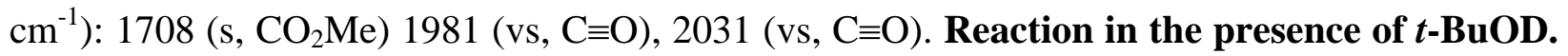
[CpFe(CO) $)_{2}$ K prepared from $16.4 \mathrm{mg}\left[\mathrm{CpFe}(\mathrm{CO})_{2}\right]_{2}(0.093 \mathrm{mmol})$ and $\mathrm{NaK}_{2.8}(0.013 \mathrm{ml})$ in 1.0 $\mathrm{ml}$ THF was mixed with $62.5 \mathrm{mg}(0.83 \mathrm{mmol}) t$-BuOD, an internal standard, cooled to $-50^{\circ} \mathrm{C}$ and $23 \mathrm{mg}$ of compound $6(0.095 \mathrm{mmol})$ was introduced. Part of the reaction solution $(\sim 0.25 \mathrm{ml})$ was transferred into NMR sample and the rest separated on a TLC plate (Silufol UV-254, twice eluted with petroleum ether: $\mathrm{Et}_{2} \mathrm{O}=4: 1$ ). The lower part of the broad second band afforded $4.2 \mathrm{mg}$ of $\mathbf{E}-\mathbf{C}_{6} \mathbf{H}_{5} \mathbf{C H}=\mathbf{C D}\left(\mathbf{C O}_{2} \mathbf{M e}\right)(0.026 \mathrm{mmol}$, containing about $10 \%$ of the undeuterated methyl cinnamate). ${ }^{1} \mathrm{H}$ NMR $(\delta, \mathrm{THF}): 7.66$ [t(1:1:1), $\left.J_{\mathrm{H}-\mathrm{D}}=2.3 \mathrm{~Hz}, 1 \mathrm{H}, \mathrm{CH}=\right], 7.59\left(\mathrm{~m}, 2 \mathrm{H}, \mathrm{C}_{6} H_{5 \text { ortho }}\right.$ ), 7.38-7.34 (m, 3H, $\mathrm{C}_{6} \mathrm{H}_{5 m e t a+}$ para), $3.72\left(\mathrm{~s}, \mathrm{CH}_{3}\right)$.

\section{Acknowledgements}

This work was financially supported by the Grant of the President of the Russian Federation for the State Support of the Leading Research Schools (Grant № HIII -1611.2003.3)

\section{References and Notes}

1. (a) King, R.B. Advan. Organometal. Chem. 1964, 2, 180. (b) Comprehensive Organometallic Chemistry, Wilkinson, G., Ed.; Pergamon Press: Oxford, 1982; Vol. 3, p 648. (c) Davison, A.; Ellis, J. E. J. Organomet. Chem. 1972, 36, 113.

2. Prezzavento, B. A.; Kuivila, H. G. J. Org. Chem. 1987, 52, 929.

3. (a) Dessy, R.E.; Pohl, R. L.; King, R.B. J. Am. Chem. Soc. 1966, 88, 5121. (b) Lai, Ch.-K.; Feighery, W.G.; Zhen, Y.; Atwood, J.D. Inorg. Chem. 1989, 28, 3929.

4. Pearson, R. G.; Figdore, P. E. J. Am. Chem. Soc. 1980, 102, 1541.

5. Schrauzer, G. N.; Deutsch, E. J. Am. Chem. Soc. 1969, 91, 3341.

6. Stolzenberg, A. M.; Stershic, M. T. J. Am. Chem. Soc. 1988, 110, 5397.

7. Suzuki, H.; Nakamura, T. Synthesis 1992, 6, 549.

8. Dodd, D.; Johnson, M.D.; Meeks, B.S.; Titchmarsh, D. M.; Van Duong, K.N.; Gaudemer, A. J. Chem. Soc., Perkin Trans. 2 1976, 1261.

9. (a) Schrauzer, G.N.; Windgassen, R.J. J. Am. Chem. Soc. 1967, 89, 1999. (b) Tada, M.; Kubota, M.; Shinozaki, H. Bull. Chem. Soc. Jpn. 1976, 49, 1097. (c) Stang, P. J.; Datta, A. K. 
J. Am. Chem. Soc. 1989, 111, 1358. (d) McCauley, K. M.; Wilson, S. R.; van der Donk, W. A. Inorg. Chem. 2002, 41, 393 (e) Rich, A. E.; DeGreeff, A. D. ; McNeill, K. J. Chem. Soc., Chem. Commun. 2002, 234.

10. Hill, D.H.; Parvez, M.A.; Sen, A. J. Am. Chem. Soc. 1994, 116, 2889.

11. Conry, R.; Mayer, J.P. Organometallics 1991, 10, 3160.

12. Wursthorn, H.R.; Kuivila, H.G.; Smit, G.F. J. Am. Chem. Soc. 1978, 100, 2779.

13. (a) Mitchell, T.N.; Reimann, W. Organometallics 1986, 5, 1991. (b) Rot, N.; de Kanter, F.J.J.; Bickelhaupt, F.; Smeets, W.J.J; Spek, A. L. J. Organomet. Chem. 2000, 593, 369.

14. (a) Maffeo, C. V.; Marchese, G.; Naso, F.; Ronzini, L. J. Chem. Soc., Perkin Trans. 1. 1979, 92. (b) Whitesides, G. M.; Fischer, W. F., Jr.; San Filippo, J., Jr.; Bashe, R. W.; House, H. O. J. Am. Chem. Soc. 1969, 91, 4871.

15. Collman, J. P.; Brauman, J. I.; Madonik, A. M. Organometallics 1986, 5, 310 and references cited therein.

16. Postigo, A.; Vaillard, S. E.; Rossi, R. A. J. Organomet. Chem. 2002, 656, 108.

17. Cabaret, D.; Maigrot, N.; Welvart, Z.; Van Duong, K. N.; Gaudemer, A. J. Am. Chem. Soc. 1984, 106, 2870.

18. (a) Bruce, M. I.; Sharrocks, D. N.; Stone, F. G. A. J. Chem. Soc. A 1970, 680. (b) Bruce, M. I.; Stone, F. G. A. J. Chem. Soc. A 1966, 1837. (c) Fenton, D. E.; Massey, A. G. Tetrahedron 1965, 21, 3009.

19. Rossi, R. A.; Pierini, A. B.; Peñeñory, A. B. Chem. Rev. 2003, 103, 71.

20. (a) Okabe, M.; Tada, M. Chem. Lett. 1980, 831. (b) Ashby, E. C.; Su, W. Y.; Pham, T. N. Organometallics 1985, 4, 1493. (c) Krusic, P. J.; Fagan, P. J.; San Filippo, J. J. Am. Chem. Soc. 1977, 99, 250.

21. Artamkina, G. A.; Sazonov, P. K.; Ivushkin, V. A.; Beletskaya, I. P. Chem. Eur. J. 1998, 4, 1169.

22. Ivushkin, V. A.; Sazonov, P. K.; Artamkina, G. A.; Beletskaya, I. P. J. Organomet. Chem. 2000, 597, 77.

23. Sazonov, P. K.; Artamkina, G. A.; Khrustalev, V. N.; Antipin, M. Yu.; Beletskaya, I. P. J. Organomet. Chem. 2003, 681, 59.

24. Bolton, R.; Sandall, J. P. B. J. Chem. Soc., Perkin Trans.1 1976, 2, 1545.

25. Grady, B. J.; Dittmer, D. C. J. Fluor. Chem. 1990, 50, 151.

26. Sazonov, P. K.; Artamkina, G. A.; Beletskaya, I. P. Zh. Org. Khim. 2001, 37, 515 [Russ. J. Org. Chem. 2001, 37, 480 (Engl. Transl.)].

27. Artamkina, G.A.; Shtern, M.M.; Sazonov, P.K.; Beletskaya, I.P. Zh. Org. Khim. 1996, 32, 1319 [Russ. J. Org. Chem. 1996, 32, 1271 (Engl. Transl.)].

28. It was shown in a special experiment that $t$-BuOH does not protonate carbonylate anions under reaction conditions employed, nor does it react with halo(acyl)rhenates or $\sigma$-aryl(vinyl) iron complexes.

29. (a) Darst, K. P.; Lukehart, C. M. J. Organomet. Chem. 1979, 171, 65. (b) Parker, D.W.; Marsi, M.; Gladysz, J. A. J. Organomet. Chem. 1980, 194, C1. 
30. (a) Chambers, R.D.; Close, D.; Williams, D.L.H. J. Chem. Soc., Perkin Trans. 2 1980, 778. (b) Bolton, R.; Sandall, J.P.B. J. Chem. Soc., Perkin Trans. 2 1978, 137. (c) Sauvetre, R.; Normant, J.-F.; Bull. Soc. Chim. 1972, 3202.

31. (a) Striejewske, W. S.; See, R. F.; Churchill, M. R.; Atwood, J. D. Organometallics 1993, 12, 4413. (b) Miholova, D.; Vlcek, A.A. Inorg. Chim. Acta 1980, 43, 43.

32. Reutov, O. A.; Beletskaya, I. P.; Butin, K. P. CH-acids, Nauka: Moscow, 1980; pp 19-101 (in Russian).

33. Ellis, J. E.; Flom, E. A. J. Organomet. Chem. 1975, 99, 263.

34. Sazonov, P. K.; Shtern, M. M.; Artamkina, G. A.; Beletskaya, I. P. Zh. Org. Khim. 1998, 34, 1807 [Russ. J. Org. Chem. 1998, 34, 1736 (Engl. Transl.)].

35. Moureu, H.; Chovin, P.; Garein, M.; Ventrillard, J. Bull. Soc. Chim. Fr. 1952, 19, 296.

36. Seyferth, D. J. Organomet. Chem. 1964, 1, 437.

37. Nesmeyanov, A. N.; Rybinskaya, M. I.; Rybin, L. V., Kaganovich, V. S., Petrovsky, P. V. J. Organomet. Chem. 1971, 31, 257.

38. Artamkina, G. A.; Milchenko, A. Yu.; Bumagin, N. A.; Beletskaya, I. P.; Reutov, O. A. Metallorganicheskaya Khimia 1988, 1, 34 [Organomet. Chem. USSR 1988, 1, 17 (Engl. Transl.)].

39. (a) Nitay, M.; Rosenblum, M. J. Organomet. Chem. 1977, 136, C23. (b) Sazonov, P. K.; Shtern, M. M.; Artamkina, G. A.; Beletskaya, I. P. Zh. Org. Khim. 1998, 34, 1448 [Russ. J. Org. Chem. 1998, 34, 1435 (Engl. Transl.)]. 